\title{
LEARNING IN LOCKDOWN: A CASE STUDY OF INTERNATIONAL STUDENT EXPERIENCES OF THE COVID-19 LOCKDOWN
}

\author{
Bradley Hannigan and Sarvesh Saini
}

\section{INTRODUCTION}

At the time of writing, in July 2020, there are 12.9 million cases of COVID-19 with 567,000 deaths globally. The United States of America leads this tally followed by Brazil, India, and Russia (Strongman, 2020). In contrast, Aotearoa New Zealand has 25 cases, all of which are in isolation (Strongman, 2020). Whilst internally the news is good, externally the virus is rampant around the world. There are currently question marks around if and when the borders will open again. It is clear that COVID-19 is different from other pandemics (for example, SARS, MERS, Ebola) in that it is truly global in its reach (Fernandes, 2020).

Businesses around the globe have been deeply impacted by the lockdown in various countries, with some commentators claiming that world economies are heading into a major recession (Carlsson-Szlezak, Reeves, \& Swartz, 2020). For importers and exporters, it is clearly not a case of business as usual. Education, as well, has faced major disruption with early childhood services, schools, and tertiary institutions closed over the lockdown period, only returning to face-to-face after 18 May 2020 (Russell, 2020). Since then, the education infrastructure has returned to normal although now with a pressing issue at hand.

At 11.59pm on March 15, 2020, Aotearoa New Zealand officially went into full (Alert Level 4) lockdown to halt the spread of COVID-19. On 28 April, 2020, Level 4 lockdown ended with a drop to Level 3. The country remained at Level 3 until I 4 May, 2020. This aggressive strategy worked for the country with a reduction to Level I occurring on 8 June, 2020 (Cousins, 2020). In July 2020, Aotearoa New Zealand is still at Alert Level I, the borders are still closed to international visitors, and isolation facilities are implementing and revising plans to ensure the safe isolation of those entering the country. The touted 'new normal' is anything but normal.

Whilst border closure protects the population from the ongoing spread of COVID-19, it also cuts off an important source of revenue for schools and tertiary institutions: international students. Overnight, the flow of international students into educational institutions stopped, and it has not yet restarted. International students are worth around $\$ 5$ billion a year and tertiary education institutions in particular are lobbying hard for change (Cooke, 2020). The financial need to replace these students is such that some tertiary institutions are considering chartering their own flights into the country (Wiltshire, 2020b) as the threat of redundancies and four-day working weeks resonate through the sector (Wiltshire, 2020a). Nowhere is the human capital of education felt so dramatically as when the flow of income stops and when the flow of students halts, as happened after the Christchurch earthquakes of 2010 (Carter, Bell, Ali, McKenzie, \& Wilkinson, 20I4; Healey, 20II), and disasters such as the L'Aquila earthquake of 2009 (Di Pietro, 2017) and Hurricance lke of 2008 (Esnard, Lai, Wyczalkowski, Malmin, \& Shah, 20l8). 
Aside from, and alongside the human capital cost of disasters such as those mentioned above are the human costs. Carter et al. (2014) noticed not only decreased academic functioning but also increased anxiety and stress. Kemp, Helton, Richardson, Blampied and Grimshaw (20 II) found that in the month after the 2010 Darfield Earthquake, students also reported increased anxiety, stress, and loss of sleep. Thamtanajit (2020) also noted these problems after the $201 \mathrm{I}$ floods in Thailand, as did DeVaney, Carr and Allen (2009) in the aftermath of Hurricane Katrina in 2005. From these studies, it is clear that disasters effect more that the bottom line for tertiary institutions: they affect students both academically and psychologically. These studies, however, focus on localised natural events. COVID-19 is not localised and is an ongoing event. At the time this article was written there is still little known about the virus and no certain way to forecast an end to the disruption. For example, the state of Victoria entered and exited lockdown at a similar time to Aotearoa New Zealand, but has now re-entered a level three-type lockdown after a second and more widespread outbreak (Smee \& Karp, 2020). Fear that Aotearoa New Zealand might go a similar way maintains the pressure to keep borders closed.

This article is an explorative case study of how international students at one Aotearoa New Zealand tertiary institution experienced the lockdown, guided by the research question "how did international students experience the Covid-19 lockdown?" This article reports how this group of students coped with lockdown and the struggles they faced. The case study approach was adopted as an accepted approach for exploring lived experience and social phenonmena (Noor, 2008). The aim of this research was to give voice to those caught up in the struggle to maintain a focus on studies at a time when the rest of the world appeared to be falling apart. This research draws on those experiences, collected through both surveys and interviews, to provide a snapshot into how one group of students continued their learning, in the hope that it will enrich the perspectives of teachers who work with international students to keep the learning alive in these unprecedented times.

Given the unique global phenonmenon that we are currently living through, this article relies less on a review of literature, for there is little to be reviewed, and has a focus on reporting findings of surveys and interviews. This study is one of the first pieces of empirical research to be reported on international student experiences of COVID-19 lockdown in Aotearoa New Zealand.

\section{METHODOLOGY}

This article reports on research undertaken as part of a Masters degree in Applied Management at an Aotearoa New Zealand tertiary institution. The approach taken is constructivist (Guba \& Lincoln, 2005) in so far as the author constructs an understanding of participants' experiences as opposed to measuring those experiences. The approach taken is inductive as the aim of the research was to give voice to a particular group of participants (international students) and to make sense of their experiences to form an understanding of the key themes that emerged. The author did not develop a conceptual framework in advance of the research, which is consistent with the inductive thematic approach to data analysis (Guest, MacQueen, \& Namey, 2012).

The data collection was carried out in a small Aotearoa New Zealand city between 15 and 22 June 2020. Data was collected by online survey $(n=50)$ and through interviews of students currently enrolled in study $(n=6)$. Survey data were analysed using descriptive statistics, and qualitative data from the survey and interviews were analysed using inductive thematic analysis techniques. Category B ethical approval was granted for this research on 13 May, 2020. 


\section{FINDINGS}

The findings of this research are organised into four emergent themes: mental and physical wellbeing, academic disruption, financial instability, and concern about or from family. These themes were found to intersect.

\section{Mental and Physical Wellbeing}

The COVID-19 lockdown impacted participants a great deal. Eighty-six per cent of the sample said that they were adversely affected by the COVID-19 lockdown. The level of impact varied from person to person. A quarter of the participants stated they were greatly affected by the lockdown while a third reported they were impacted slightly. Male respondents were more likely to report adverse affects of lockdown (60 per cent of males) than females (48 per cent of females). It was found that females were more likely to report psychological stress (56 per cent of females) than males (43 per cent of males). Females in the group were more likely to experience anxiety but did not report experiencing sleep-disorders or depression. Thirteen percent of females experienced physical illness during the lockdown, whereas no males reported being physically sick. It was found that those students who were staying with their families reported being more stressed (63 per cent of those staying with families) than those who did not have their families with them (43 per cent of students not staying with their families).

When questioned on the source of stress, some participants stated that the continued need to meet deadlines was a key stressor. For example, one participant stated "I tried to complete the assignments but not being able to write more than three or four lines felt like wasting my time, which created more stress." Another found the source of stress to be financial: "there was pressure on my finances which added extra stress" whereas others identified disrupted travel plans for family, the crashing job market, and a sense of being trapped in New Zealand as sources of their stress.

\section{Academic Disruption}

It was found that the COVID-19 lockdown disrupted the academic achievement for participants. Eighty-three percent of respondents reported that due to lockdown, their academic goals were affected. There was no noted difference between male and female groups. Those who lost their job as a result of the lockdown reported facing more difficulties with their academic study (44 per cent), than those that retained their jobs over lockdown (2I per cent).

All interviewees agreed that due to the lockdown, they faced disruption in their study. During the lockdown, they were not able to access the facilities of their study institution and had to switch to online classes, which required some time and effort for them to adjust. They found that due to the changing style of lecture delivery, they had to find new ways to communicate with tutors, and all reported that this created more pressure on them. For example one participant stated "we do not have face-to-face classes with tutors, and that prevents you from asking questions and not having an opinions of other students on a topic, which makes it hard to understand." Another participant reported "I am not able to understand any topic due to not having the face-to-face classes, which built more stress." Another participant pointed out that "we were asked to study from home, which was hard to do and required flexibility in the course."

\section{Financial Stability}

This research found that 18 out of the 50 participants lost their job during the lockdown. Of the respondents who lost jobs, 44 per cent felt pressure in their academic study as well. The participants aged 25 to 34 were found to be most likely to be adversely financially affected by the lockdown, whereas respondents between the ages 35 to 44 reported being less financially affected by the lockdown. 
In the interviews, all participants agreed that they felt extra pressure due to the financial loss they suffered during the lockdown. One participant stated "I went through financial loss, the shop where I use to work that shop was closed and not get any word from the owner about the salary." They went on to say that the wage subsidy given by the government only covered half their rent and living expenses. Two other participants had both lost their jobs at the beginning of the lockdown and were suffering financial hardship as a result. Another participant stated "I lost my part-time job due to redundancy. During this period, no organisations were hiring new staff, and therefore no jobs were available for at least three months, which made it difficult for me to manage my expenses." All interviewees stated that financial pressures had an adverse effect on their ability to focus on their studies.

\section{Concern About or From Family.}

The findings of the survey indicated that out of 50 students, 43 (86 per cent) were living without their families in New Zealand. It was found that 63 per cent of that group felt family pressure, but the level of felt pressure varied from person to person. All interview participants felt family pressure as they were not with their family. As a result, all participants reported they were unable to focus on their studies. The leading cause of their stress was their concern about the wellbeing of their family and not wanting their families to worry about them. One participant stated "my elder son [living outside of Aotearoa New Zealand] has respiratory problems. They faced the medical shortage, food shortage. As a father, my stress was three to four times higher as compared to any other student. All these things stressed me a lot." Another participant highlighted that his families concern for him being alone in Aotearoa New Zealand caused him stress: "my family was quite worried about my health, and one of my cousins died in New York because of COVID-19. My family was concerned about me, which puts extra stress."

\section{DISCUSSION}

The findings of this research highlight the experiences of a small number of international students living in Aotearoa New Zealand during the lockdown. Like students in previous literature on post-disaster teaching and learning (for example Carter et al., 2014), these students reported that psychological and social pressures affected their ability to focus on their studies. However, for this group of students, financial stressors added to their woes. These findings confirm Maslow's (1968) idea that it is difficult to focus on intellectual achievements when faced with physical and psychological trauma.

It is difficult to grasp the effect of being so far from home and family, in a foreign country, studying during a time of pandemic. These findings tell a story of struggle that goes beyond passing or not passing a course, and speaks more of survival in the face of adversity. Participants identified the loss of contact as being particularly difficult to manage, whereas others identified a shift in focus to financial survival as a barrier to "meeting their academic goals." For this group of international students, the ability to adapt in the face of uncertainty and to continue their studies went hand in hand. The findings of this is similar to those of Kemp et al. (201I) where the act of living through a disaster situation has an ongoing impact on perceived wellbeing.

Living with family while studying was not a protection against stresses felt in lockdown. Financial insecurity coupled with a concern for loved ones in country and at home contributed to experienced anxiety and worry for many participants in this research. While Aotearoa New Zealand appears to have COVID-19 under control (Strongman, 2020), many of the home countries of international students do not. This is a source of ongoing concern for many. Again, as Maslow (1968) concluded, it is difficult to focus on self-actualisation when belonging and security are in doubt. The participants in this research experienced this first hand, and it is not over: COVID-19 has not yet finished exacting its toll on the world (Strongman, 2020).

Unlike the Christchurch earthquakes or Hurricane Katrina, COVID-19 is silent and invisible. Unlike similar pandemics, it is global in its reach (Cousins, 2020), and at the time of writing is rampant and evolving. A return to their home countries, to family, was not an option in the lockdown and is still not an option over a month into 
Level I status. Questions over the availability of jobs or whether loved ones will be allowed through the border to reunite with them were asked during the lockdown and continue to be asked. These are contemporary issues that weighed heavily on the minds of the international students in this study. Marking guides and rubrics tend to pale in comparison with the raw facts of daily existence for many international students. Participants agreed that it was difficult to focus on their studies when they lost their job.

This research shows that teaching and learning for international students post the COVID-19 lockdown involves understanding some of the pressures faced by this particularly vulnerable group. Some participants lost their jobs and were struggling financially, some had family at risk of contracting the virus in their home countries, and most had no way of getting home due to border restrictions in their own countries. Within such a dynamic and uncertain context, teaching must therefore look beyond academic achievement to recognise the achievement that exists in remaining academically focused in such hostile times. The participants in this research had to learn how to adapt, moving from face-to-face to online provision but more importantly to the prospect of living in a foreign country without a job and under the cloud of impending recession (Carlsson-Szlezak et al., 2020).

Yet the drive to open the borders to international students continues (Wiltshire, 2020b). In many ways it has to; the education sector in Aotearoa New Zealand has built a $\$ 5$ billion dependency on this market. This research has found that increasing international student numbers is only part of the problem for education in Aotearoa New Zealand. To keep them psychologically, emotionally, and financially safe while they are here is an added responsibility. At the end of May 2020, Victoria, Australia. COVID-19 cases were in single digits; on June 6, 2020 there were no COVID-19 cases reported (Vaughan \& Ky, 2020). Fast forward to early July and Victoria has reentered a level three lockdown with daily cases consistently over 200. If Aotearoa New Zealand were to re-enter lockdown, as is always the possibility, how well prepared will we be to support the international students in the care of our education system? What have we learnt from our experience thus far?

\section{CONCLUSION}

This article has reported on a small scale research project involving international students undertaken in a tertiary institution soon after the COVID-19 lockdown, once Alert Level I had been resumed. The aim of the research was to give voice to the experiences of international students and to reflect on some of the consequences of those experiences for teaching and learning. The research question that guided this exploration was 'how did international students experience the COVID-19 lockdown?' The key finding of this research was that participants' experiences differed, but academic challenges were connected to psychological, social, and financial hardship experienced by participants.

The COVID-19 situation is globally ongoing. This article acts as a reminder that if academic success is to be commodified, then the psychological, social and financial wellbeing of students needs to be considered as part of the marketing mix. This is particularly true for international students in a time of crisis.

Dr. Bradley Hannigan teaches research methods and supervises masters' theses at Nelson Marlborough Institute of Technology Ltd. His research interests are philosophy of education, qualitative research, strategic management and organisational change management.

(10) https://orcid.org/0000-0003-2940-39/4

Sarvesh Saini is a Master of Applied Management student at Nelson Marlborough Institute of Technology Ltd. His interests are in applied food store management and logistics. 


\section{REFERENCES}

Carlsson-Szlezak, P., Reeves, M., \& Swartz, P. (2020, March 03). What Coronavirus Could Mean for the Global Economy. Harvard Business Review. Retrieved from https://hbr.org/2020/03/what-coronavirus-could-mean-for-the-global-economy

Carter, F. A., Bell, C. J., Ali, A. N., McKenzie, J., \& Wilkinson, T. J. (2014). The impact of major earthquakes on the psychological functioning of medical students: a Christchurch, New Zealand study. NZ Medical Journal, 127(1398), 54-66.

Cooke, H. (2020, June 12). Coronavirus: National unveil plan to bring international students back into country, with universities handling quarantine. Retrieved from https://www.stuff.co.nz/national/politics/300033394/coronavirus-national-unveilplan-to-bring-international-students-back-into-country-with-universities-handling-quarantine

Cousins, S. (2020). New Zealand eliminates COVID-19. The Lancet, 395(I0235), 1474.

DeVaney, T. A., Carr, S. C., \& Allen, D. D. (2009). Impact of Hurricane Katrina on the Educational System in Southeast Louisiana: One-Year Follow-Up. Research in the Schools, 16(I).

Di Pietro, G. (20I8). The academic impact of natural disasters: evidence from L'Aquila earthquake. Education Economics, 26(I), 62-77.

Esnard, A. M., Lai, B. S., Wyczalkowski, C., Malmin, N., \& Shah, H. J. (2018). School vulnerability to disaster: examination of school closure, demographic, and exposure factors in Hurricane Ike's wind swath. Natural Hazards, 90(2), 513-535.

Fernandes, N. (2020). Economic effects of coronavirus outbreak (COVID-19) on the world economy. IESE Business School Spain, I-26. Retrieved from https://papers.ssrn.com/sol3/papers.cfm?abstract_id=3557504

Guba, E. G., \& Lincoln, Y. S. (2005). Paradigmatic controversies, contradictions, and emerging confluences. In N. K. Denzin \& Y. S. Lincoln (Eds.), The Sage handbook of qualitative research. Thousand Oaks, CA: Sage Publications, 191-215.

Guest, G., MacQueen, K. M., \& Namey, E. E. (2012). Introduction to applied thematic analysis. Applied thematic analysis, 3, 20.

Healey, N. (2011). The 2010 and 201 I Canterbury earthquakes and organisational learning at the University of Canterbury: Does practice make perfect? Journal of Management and Organization, 17(6), 850-856.

Kemp, S., Helton, W. S., Richardson, J. J., Blampied, N. M., \& Grimshaw, M. (20I I). Sleeplessness, stress, cognitive disruption and academic performance following the September 4, 2010, Christchurch earthquake. Australasian Journal of Disaster and Trauma Studies, 2.

Maslow, A. H. (1968). Toward a psychology of being. New York: Van Nostrand Reinhold.

Noor, K. B. M. (2008). Case study: A strategic research methodology. American Journal of Applied Sciences, 5(I I), I602-I604.

Russell, E. (2020, May 18). Covid-19 coronavirus: Kiwis head back to office and school after months in lockdown. NZ Herald. Retrieved from https://www.nzherald.co.nz/nz/news/article.cfm?c_id= I\&objectid=12332546

Strongman, S. (2020, June 13). Covid-19 pandemic timeline: How the coronavirus started, spread and stalled life in New Zealand. Radio NZ. Retrieved from https://shorthand.radionz.co.nz/coronavirus-timeline/

Smee, B., \& Karp, P. (2020, July 12). Victoria records 273 new Covid- 19 cases and flags return to remote schooling in lockdown areas. The Guardian. Retrieved from https://www.theguardian.com/australia-news/2020/jul//2/victoria-records-273-newcovid-19-cases-and-flags-return-to-remote-schooling-in-lockdown-areas

Thamtanajit, K. (2020). The impacts of natural disaster on student achievement: Evidence from severe floods in Thailand. The Journal of Developing Areas, 54(4)

Vaughan, R., \& Ky, J. (2020, July II). A timeline of how Melbourne landed back in stage 3 lockdowns. 7 News. Retrieved from https://7news.com.au/lifestyle/health-wellbeing/a-timeline-of-how-melbourne-landed-back-in-stage-threelockdowns-c-||57684

Wiltshire, L. (2020a, April 30). Redundancies, 4-day working week and paycuts all on the table as Victoria battles $\$ 40$ million deficit. Stuff. Retrieved from https://www.stuff.co.nz/national//21353923/redundancies-4day-working-week-and-paycutsall-on-the-table-as-victoria-battles-40-million-deficit? $r m=a$

Wiltshire, L. (2020b, June 0I). Charter flights considered to bring international students back to Wellington. Stuff. Retrieved from https://www.stuff.co.nz/national//2168786//charter-flights-considered-to-bring-international-students-back-towellington? $r m=a$ 